\title{
Antibacterial efficacy of local plants and their contribution to public health in rural Ethiopia
}

\author{
Gutema Taressa Tura, Wondwossen Birke Eshete and Gudina Terefe Tucho*
}

\begin{abstract}
Background: Proper hand hygiene with soap and detergents prevents the transmission of many infectious diseases. However, commercial detergents are less likely to be accessible or affordable to poor people in remote rural areas. These people traditionally use some plant parts as a detergent even though their antibacterial activity has not been yet investigated. Therefore, this study aims to determine the antibacterial activities of some of the plants against bacteria isolated from humans.

Methods: Plants selected for this study are Phytolacca dodecandra fruits, Rumex nepalensis leaves, Grewia ferruginea bark and leaves. The samples of these plants were collected from rural areas of Jimma town based on their ethno-botanical survey and information on their local use. Acetone was used as a solvent to extract the bioactive constituents of the plants. The antibacterial activities of the plants were evaluated against reference strains and bacteria isolated from humans using disc diffusion and macro dilution methods.

Results: The plant extracts have shown varying antimicrobial activities against the bacterial species tested. Susceptibility testing shows zones of inhibition ranging from $8.0 \pm 1.0 \mathrm{~mm}$ to $20.7 \pm 5.5 \mathrm{~mm}$. The MIC and MBC of the plants against the bacterial species tested were 3.13 and $12.5 \mathrm{mg} / \mathrm{ml}$ respectively. These variations are attributed to different concentrations of the bioactive constituents of the extracts like saponins, tannins, flavonoids and terpenoids.

Conclusion: The studied plants can contribute to achieve better personal hygiene since they are effective against different bacterial agents and are freely available in rural areas.
\end{abstract}

Keywords: Plants, Phytochemical, Hand hygiene, Antibacterial, Antimicrobial resistance, Public health

\section{Background}

Soap has been used for personal hygiene for many centuries. The effectiveness of soap to clean dirt is based on its detergent properties. However, soaps containing antiseptic agents in addition to detergents are available since the 19th century $[1,2]$. In particular, hands perform several activities through which they come into contact with contaminated objects. Hands will be routes for disease transmission if proper hand hygiene is not performed. In fact many infectious diseases are easily transmitted through hand contacts from the immediate environment $[3,4]$. Many of the diseases in developing

\footnotetext{
* Correspondence: guditerefe@gmail.com; gudina.terefe@ju.edu.et

Department of Environmental health Sciences and Technology, Jimma University, Jimma, Ethiopia
}

(c) The Author(s). 2017 Open Access This article is distributed under the terms of the Creative Commons Attribution 4.0 International License (http://creativecommons.org/licenses/by/4.0/), which permits unrestricted use, distribution, and reproduction in any medium, provided you give appropriate credit to the original author(s) and the source, provide a link to the Creative Commons license, and indicate if changes were made. The Creative Commons Public Domain Dedication waiver (http://creativecommons.org/publicdomain/zero/1.0/) applies to the data made available in this article, unless otherwise stated.

countries are related to fecal-oral transmission attributed to insufficient personal hygiene [5]. Hand hygiene is the simplest, most cost effective and easily applicable measure that can reduce the risk of spread of infectious diseases [6-8]. Nevertheless, the effectiveness of hand hygiene depends on the habit of using soap during washing $[7,9]$. However, better microbial removal and hygiene might be more achieved when antimicrobial detergents are used instead of plain soap and water $[1,7]$.

There are many effective antimicrobial cleaning products available to provide better cleaning services. In particular, alcohol based cleaning agents are effective against gram negative and gram positive bacteria despite some limitations related to short time residual effects [10,11]. Nevertheless, most effective commercial antimicrobial agents are 
less likely accessible or affordable to poor people living in remote rural areas of developing countries to meet the goal of hand hygiene [12]. Alternatively, different plants with antimicrobial properties can replace expensive commercial antimicrobial products [13, 14]. Most plant products are effective including against harmful resistant micro-organisms [15].

People in rural areas have a rich tradition of using different parts of plants for personal hygiene. For instance, Phytolacca dodecandra (P. dodecandra) fruits, Rumex nepalensis (R. nepalensis) leaves and Grewia ferruginea (G. ferruginea) leaves and bark are some of the most commonly used plants in different rural areas of Ethiopia for cleaning purposes (i.e. bathing, washing clothes etc.). There are a lot of effective different plants used for personal hygiene in different parts of the world [16-19]. Several medicinal plants have been studied for their antibacterial activities against different pathogenic bacteria species [20-22]. Many of them were also found to be effective against resistant microbial strains [16, 23]. However, the antibacterial activities of plants used for personal hygiene have not been yet determined. These plants can be cost effective alternatives to modern detergents if their antibacterial activities are determined and promoted. Studying their antibacterial activity is not only to promote them as alternatives but also to preserve indigenous knowledge about the use of local plants for personal hygiene [24]. Therefore, this study aims to evaluate the antibacterial activities of some plants used for personal hygiene against bacterial colonizing the skin. The results can be vital in the promotion of low cost and effective cleaning materials in rural areas and in preserving indigenous knowledge about plants used for personal hygiene.

\section{Methods}

\section{Plant sample collection and preparation}

Different parts of healthy test plants of $P$. dodecandra (local name "Andoode") fruits, $R$. nepalensis (local name
“Timiji") leaves, G. ferruginea (local name "Dhoqonu") leaves and bark were collected from rural areas within the Jimma zone. The selection of the test plants was based on ethno-botanical surveys and relevant information of traditional use of the plants as detergents [21, 25]. The parts of the plants considered for sampling are frequently used for cleaning purposes.

The collected samples were washed under running clean tap water to eliminate adhering dust and any foreign particles and shaded to dry at room temperature for about 7-14 days. The dried samples were grinded with a mechanical grinder, sieved with a $2.5 \mathrm{~mm}$ sieve size and stored at $4{ }^{\circ} \mathrm{C}$ until considered for extraction [26]. The bioactive constituents of the plants were extracted with acetone. Acetone was selected as a solvent based on its low toxicity, easiness of extraction and easy evaporation [27]. The extraction was performed by dissolving $200 \mathrm{~g}$ of each plant's powder in $700 \mathrm{ml}$ of acetone, shaken at constant speed of $300 \mathrm{rpm}$ (HY-5A Maneuver style vibrator shaker) and filtered with Whatman No.1 filter paper. The contents were then dried and weighed for their extract yields and stored at $4{ }^{\circ} \mathrm{C}$ for microbial assay. The percentage extract yields of the plants were calculated as: Percentage extract yield $(\%)=\frac{\text { Weight of dried extract }}{\text { Weight of dried powder }}$ X100 (Table 1).

\section{Phytochemical screening}

The phytochemical screenings of the plants were made based on qualitative methods used in other studies [28-30]. Saponins, tannins, flavonoids and terpenoids were bioactive compounds considered for identification based on their antimicrobial activities [31-35]. The concentration of the constituents was determined based on their relative color strength; the deeper the color the stronger the concentration of the constituents in the extracts.

Table 1 Ethno-botanical and relevant information of the plants

\begin{tabular}{|c|c|c|c|c|c|}
\hline \multicolumn{3}{|l|}{ Name } & \multirow[t]{2}{*}{ Parts used } & \multirow[t]{2}{*}{ Traditional use } & \multirow{2}{*}{$\begin{array}{l}\text { Picture of the plant } \\
\text { part }\end{array}$} \\
\hline Scientific & Family & Local & & & \\
\hline Phytolacca dodecandra & Phytolaccaceae & Andoodee (Indodi) & Fruit & $\begin{array}{l}\text { Used for washing of clothes, } \\
\text { hands and body }\end{array}$ & \\
\hline Rumex nepalensis & Polygonaceae & Timijii (Tult) & Leaf & $\begin{array}{l}\text { Used for washing of } \\
\text { hands and hair }\end{array}$ & \\
\hline Grewia ferruginea & Tiliaceae & Dhoqonu (Lenkoata) & Leaf & Used for washing hair & \\
\hline Grewia ferruginea & Tiliaceae & Dhoqonu (Lenkoata) & Bark & Used for washing hair & \\
\hline
\end{tabular}


Identification of Saponins was made by using a foam test by adding $5 \mathrm{ml}$ of distilled water to $0.5 \mathrm{~g}$ of the extracts, shaken vigorously and observed for its frothing. Again three drops of olive oil were added and shaken vigorously for the formation of emulsions indicating the presence of saponins. The test for identification of tannins was done by mixing $0.5 \mathrm{~g}$ of the extracts with distilled water and heating on a water bath until the extracts were fully dissolved. The formation of a dark green color indicates the presence of tannins upon addition of $0.1 \%$ ferric chloride. Identification of the presence of flavonoids was made by adding $0.2 \mathrm{~g}$ of the extracts to $2 \mathrm{ml}$ of $2 \%$ solution of $\mathrm{NaOH}$. An intense yellow color was formed which turned colorless upon addition of few drops of diluted $\mathrm{HCl}$ indicating the presence of flavonoids. Finally, identification of terpenoids was made by mixing $0.2 \mathrm{~g}$ of the extracts with $2 \mathrm{ml}$ of chloroform $\left(\mathrm{CHCl}_{3}\right)$ and $3 \mathrm{ml}$ of concentrated sulfuric acid $\left(\mathrm{H}_{2} \mathrm{SO}_{4}\right)$ whereby the formation of a layer with a reddish-brown color interface indicates the presence of terpenoids.

\section{Isolation and identification of bacteria species}

Isolation and susceptibility testing of the bacterial species were done by using standardized procedures [36-38]. Isolation of the test bacteria was done by using sterile cotton swabs soaked in $0.85 \%$ sterile saline solution. The samples were taken from palms, fingers and fingernails of the left and right hands of individuals working in hospital and food handling activities and preserved at $4{ }^{\circ} \mathrm{C}$ in saline solution.

Prior to culturing, MacConkey agar, Mannitol salt agar, Xylose Lysine Desoxycholate agar (XLD agar) and selenite $\mathrm{F}$ broth were prepared according to the instruction of the manufacturer and the operating standard procedures [38, 39]. Subsequently, the swab samples were soaked in saline solution, vigorously shaken and $0.2 \mathrm{ml}$ of the solution was cultured on the media and incubated in an inverted position at $37{ }^{\circ} \mathrm{C}$ for $24 \mathrm{~h}$. The media containing inoculum was then observed for the formation of distinct isolated colonies for further sub-culturing. Colonies for sub-culture were considered based on the colony morphology of culture positive samples. Accordingly, Lactose fermenting colonies (LFCs) and non-lactose fermenting colonies (NLFCs) were characterized by pink color and pale color respectively on MacConkey agar. Small colonies surrounded by yellow zones or colonies changed the color of Mannitol Salt Agar (MSA) to yellow and white creamy colonies were also identified. Following gram staining, different biochemical and enzymatic reaction tests were done to identify bacteria into species. Therefore, we used oxidase, catalase, Klinger iron agar (KIA), lysine iron agar (LIA), Indole, Motility, Citrate, Urease, Triple sugar iron Agar (TSIA) and TSIA tests.
Due to resource constraints, classification of bacteria was done using the following basic biochemical approach $[4,38,40]$. Accordingly, the identification of Salmonella species was made by culturing the colony on Xylose Lysine Desoxycholate agar media enriched with a Selenite broth; thus colonies with a black center were identified as Salmonella species. Identification of E.coli was made by using MacConkey salt agar and fermentation of lactose with the formation of flat dry pink of irregular colonies. Identification of S.aureus was made by using Mannitol salt agar with the subsequent formation of yellow/golden colored colonies. $P$. aeruginosa identification was made by using nutrient agar and MacConkey agar. Colonies with large and irregular opaque bluish-green pigment on nutrient agar and non-lactose fermentation with colorless colonies on MacConkey agar were identified as P. aeruginosa. These species of bacteria are responsible for many communicable diseases in developing countries. In addition, most of them are resistant to ordinary antibacterial agents and are considered for the current antibacterial activity testing.

E. coli (ATCC 25922), P. aeruginosa (DSMZ 1117), S. typhimurium (ATCC 13311) and S. aureus (ATCC 25923), all American Type Culture Collections were obtained from the Microbiology lab of Jimma University as reference bacteria strains for a quality control.

\section{Antibacterial activity testing}

Inoculums for antibacterial testing were prepared by transferring pure bacteria strains grown on nutrient agar media to $5 \mathrm{ml}$ sterile physiological saline solution $(0.85 \% \mathrm{NaCl} w / v)$. The suspended turbidity was adjusted to $0.5 \mathrm{McF}$ arland standards corresponding to $1.5 \times 10^{8} \mathrm{CFU} / \mathrm{ml}$ [41]. The antibacterial activity testing of the plants was done by using a disc diffusion method [37]. The standardized suspension of bacterial strains of $1.5 \times 10^{8} \mathrm{CFU} / \mathrm{ml}$ was prepared and diffused on the Mueller Hinton agar (MHA) media with sterile swabs. Sterile filter paper discs of $6 \mathrm{~mm}$ diameter were impregnated with a $200 \mathrm{mg}$ concentration of the plant extracts dissolved in $1 \mathrm{ml}$ of DMSO, then placed on swabbed agar and incubated at $37^{\circ} \mathrm{C}$ for $24 \mathrm{~h}$. The diameters of zones of inhibition were measured in millimeters using a ruler and the average of triplicate results were presented. A positive and negative control was done by $1 \%$ phenol solution and DMSO (without plant extracts) respectively.

\section{Determining MIC and MBC of the plants}

The Minimum Inhibitory Concentration (MIC) and Minimum Bactericidal Concentration (MBC) of the plants were determined based on standard procedures and cited literatures [42-44]. Accordingly, a stock solution with the concentration of the plant extracts of 
$200 \mathrm{mg}$ in $1 \mathrm{ml}$ of DMSO was diluted using a two-fold serial dilution. This provides the series of test concentrations of $100,50,25,12.5,6.25$ and $3.13 \mathrm{mg} / \mathrm{ml}$ respectively. The plant's antibacterial activity testing was done by incubating each concentration of the extract with inoculum containing $0.1 \mathrm{ml}$ of microbial cell at $37^{\circ} \mathrm{C}$ for $24 \mathrm{~h}[45,46]$. The smallest concentration that inhibited the growth of the test bacteria was considered as MIC of the plants. The MBC of the plants was determined by transferring inoculums from MIC tubes to freshly prepared nutrient agar, incubated for $24 \mathrm{~h}$ at $37{ }^{\circ} \mathrm{C}$ with different concentrations of the extracts [23]. The smallest concentration of the extracts with no visible bacterial growth after incubation was taken as MBC.

\section{Results}

The extract yields of the plants and their phytochemical constituents

The method used for the extraction achieved varying extract yields ranging from $6.40 \mathrm{~g}$ to $15.47 \mathrm{~g}$ (Table 2). The highest percent extract yield was obtained from $P$. dodecandra fruits $(7.74 \%)$ and the lowest (3.2\%) was from G. ferruginea bark. Variations were also observed in the concentration of the phytochemical constituents of the plant parts and species. Phytochemical constituents are bioactive compounds with many antibacterial activities. Accordingly, all the evaluated plant species contain saponins, tannins and flavonoids in varying concentrations. However, terpenoids were not found in $P$. dodecandra fruits and $R$. nepalensis leaves (Table 3).

\section{Antibacterial activities of the plants}

The antibacterial activities of the plants are shown in Table 4. The data shows huge antibacterial activity variation among different plant species and parts. The extracts of the plants achieved varying zones of inhibition against both isolate and reference (standard) bacteria species. The highest zone of inhibition $(20.7 \pm 5.5 \mathrm{~mm})$ was achieved with $R$. nepalensis leaves extract against reference Salmonella strain (S. typhimerium). The zones of inhibition of $P$. dodecandra fruits, and G. ferruginea leaves and bark against different bacterial species range from $9.0 \pm 1.0$ to $16.7 \pm 1.2 \mathrm{~mm}$ (Mean \pm SD). However, all of them achieved a relatively smaller zone of inhibition against isolated bacteria than their reference counterparts. The MIC and the $\mathrm{MBC}$ of the studied plants are shown in Fig.1. Their MIC ranges from $3.13 \mathrm{mg} / \mathrm{ml}$ to $50 \mathrm{mg} / \mathrm{ml}$ while their $\mathrm{MBC}$ are between $6.25 \mathrm{mg} / \mathrm{ml}$ and $100 \mathrm{mg} / \mathrm{ml}$. This implies that a higher concentration is needed for killing bacteria than for inhibiting their growth. The G. ferruginea leaves and bark extract showed the lowest MIC and MBC against Salmonella species while $R$. nepalensis similarly showed the lowest values against $E$. coli. Relatively, larger MIC and MBC were obtained with the extract of G. ferruginea and R. nepalensis against $S$. aureus and $P$. aeruginosa.

\section{Discussion}

Evaluation of the antibacterial activities of the plants

Among modern methods of extraction, maceration is effective in extracting bioactive compounds at room temperature [47]. These compounds contain broad spectrum antibacterial agents acting against different species of bacteria [34, 35, 48, 49]. Different plant species contain different concentrations of bioactive compounds (Table 3). The variation in antibacterial activity against both test and reference bacteria is found to be attributable to variation in bioactive constituents of the plants. The variation was also significant even within the same plant when evaluated against different bacteria species. The antibacterial activity of $R$. nepalensis against Salmonella species (S. typhimurium) and P. aeruginosa is a good example. This plant showed the highest inhibition against Salmonella species and no inhibition against $P$. aeruginosa. The variation can be attributed to the high concentration of tannins and the lack of terpenoids in this plant. Nevertheless, most plant extracts achieved smaller zones of inhibition against test bacteria than reference bacterial species due to probability of antibacterial resistance with isolate species. However, all the evaluated plant extracts possess antimicrobial activity with high susceptibility pattern of low MIC and MBC. Their low MIC and MBC indicates their high efficacy against nonresistant and resistant bacteria species [50]. In particular, plants with a high concentration of flavonoids (i.e. P. dodecandra and G. ferruginea) have shown better antibacterial activity against isolate bacterial species than the remaining test plant species and parts. Literature reported flavonoids as bioactive compounds with high antimicrobial activities against resistant strains $[51,52]$.

The bioactive constituents have different mechanism of action against bacterial cells. Tannins and Flavonoids act on bacterial cells through the formation of a complex

Table 2 The extract yields of the plants

\begin{tabular}{lllll}
\hline S.No. & Plant parts & Weight of powder (gram) & Weight of extract (gram) & Percent extract yield (\%) \\
\hline 1 & P.dodecandra fruit & 200 & 15.47 & 7.74 \\
2 & R.nepalensis leaves & 200 & 7.10 & 3.55 \\
3 & G.ferruginea bark & 200 & 6.40 & 3.20 \\
4 & G.ferruginea leaves & 200 & 11.14 & 5.57 \\
\hline
\end{tabular}


Table 3 Phythochemical constituents of the plants

\begin{tabular}{llllll}
\hline S. No. & Phytochemical components & P.dodecandra fruit & R.nepalensis leaf & G.ferruginea bark & G.ferruginea leaf \\
\hline 1 & Saponins & ++ & + & +++ & +++ \\
2 & Tannins & ++ & +++ & ++ & + \\
3 & Flavonoids & +++ & + & ++ & ++ \\
4 & Terpenoids & - & - & ++ & +++ \\
\hline
\end{tabular}

Key: $=$ absent; $+=$ present in small amount; $++=$ Present in moderate amount; $+++=$ present in high amount

with cell walls, binding to proteins, disruption of membranes and inhibition of enzymes. Antibacterial effects of saponins are achieved through inactivation of extracellular medium and membranes of the bacterial cell [13]. Saponins-rich extracts are less active against $S$. aureus compared to gram negative bacteria like E.coli and $P$. aeruginosa [53]. Studies indicated that most pathogenic bacteria such as S.aureus and E.coli isolated from the hands of health workers are resistant to many antimicrobial agents $[54,55]$. However, the plants evaluated in the current study showed moderate to highest antibacterial activities against these organisms probably due to availability of bioactive compounds in high concentration. In particular, plants containing tannins, flavonoids and saponins are effective against resistant bacterial species [16]. This shows the effectiveness of the studied plants against various bacterial species.

\section{Contribution of the plants to rural sanitation and public health}

Most people living in rural areas of developing countries do not have sufficient income to afford the costs of modern antibacterial detergents. Moreover, most of them do not have sufficient awareness of the use of antibacterial detergents as a first line of defense against many communicable diseases $[9,56]$. In addition, most of them do not have access to basic sanitation and clean water supply. Lack of access to basic sanitation and clean water can be solved by building the system providing the services. However, fecal-oral contamination and transmission of related diseases are inevitable if good hand hygiene is not practiced [57]. In areas where commercial detergents are not available or affordable the studied plants can be used as an alternative. These plants are available in most rural areas throughout the year to use without any costs. Moreover, research shows that $S$. aureus, E. coli and $P$. aeruginosa species are resistant to most antibacterial agents [27]. However, all the test plants in the current study have shown antibacterial activity against these organisms with varying concentrations. This implies the possibility to use the ingredients of the plants in the formulation of commercial antibacterial detergents. However, the current study was not designed to provide its efficacy against resistant bacteria in a short contact time. Therefore, further investigation is needed to determine their efficacy with a short contact time. Nevertheless, the results are robust in promoting plant materials for hand hygiene in remote rural areas where commercial detergents are not available or not affordable to the poor.

\section{Conclusion}

The current study evaluated the antibacterial activities of three plant species traditionally used as detergents in rural areas of Ethiopia. All the test plant species have shown moderate to high antibacterial activity against the test bacteria species. P.dodecandra fruit and G.ferruginea bark and leaves have shown zones of inhibition ranging from 8 to $11 \mathrm{~mm}$ against $E$. coli, S. aureus, $P$. aeruginosa and Salmonella species. $R$. nepalensis also has shown zones of inhibition ranging from 9 to $12 \mathrm{~mm}$ against all test bacterial species except $P$. aeruginosa. In addition, all of them achieved better antibacterial activity with the smallest concentration of the extracts (i.e. lowest MIC

Table 4 Zone of inhibition (mean $\pm \mathrm{SD}, n=3$ ) of the plants extracts in $\mathrm{mm}$

\begin{tabular}{|c|c|c|c|c|c|c|c|c|}
\hline \multirow[t]{3}{*}{ Extracts } & \multicolumn{8}{|c|}{ Bacteria strains } \\
\hline & \multicolumn{2}{|l|}{$\overline{\text { E.coli }}$} & \multicolumn{2}{|l|}{ S. aureus } & \multicolumn{2}{|c|}{ P. aeruginosa } & \multicolumn{2}{|c|}{ Salmonella spp. } \\
\hline & Isolate & Ref. & Isolate & Ref. & Isolate & Ref. & Isolate & Ref. \\
\hline P.dodecandra fruits & $9.7 \pm 0.6$ & $11.3 \pm 1.5$ & $10.3 \pm 2.1$ & $12.3 \pm 2.3$ & $9.3 \pm 2.5$ & $12.0 \pm 1.0$ & $11.0 \pm 1.0$ & $16.3 \pm 0.6$ \\
\hline G. ferruginea leaf & $10.0 \pm 1.0$ & $12 \pm 0.0$ & $9.7 \pm 0.6$ & $11.7 \pm 0.6$ & $9.0 \pm 1.0$ & $10.7 \pm 1.5$ & $11.0 \pm 1.0$ & $14.3 \pm 0.6$ \\
\hline G. ferruginea bark & $8.0 \pm 1.0$ & $12.0 \pm 2.6$ & $9.0 \pm 1.0$ & $11.3 \pm 2.9$ & $9.7 \pm 2.5$ & $10.3 \pm 1.2$ & $9.3 \pm 0.6$ & $16.7 \pm 1.2$ \\
\hline R. nepalensis leaf & $9.0 \pm 1.0$ & $10.3 \pm 0.6$ & $9.0 \pm 1.0$ & $12.0 \pm 3.5$ & $\mathrm{Nl}$ & $\mathrm{NI}$ & $10.0 \pm 1.0$ & $20.7 \pm 5.5$ \\
\hline Phenol & $7.3 \pm 0.6$ & $8.7 \pm 1.5$ & $8.0 \pm 1.0$ & $8.7 \pm 1.2$ & $7.7 \pm 0.6$ & $8.0 \pm 1.7$ & $5.0 \pm 4.4$ & $5.0 \pm 4.4$ \\
\hline DMSO & 0 & 0 & 0 & 0 & 0 & 0 & 0 & 0 \\
\hline
\end{tabular}

Key: \pm SD = Standard Deviation, Ref. = Reference bacteria strain, $\mathrm{Nl}=$ No Zone of inhibition, $\mathrm{n}=$ number of replicates 


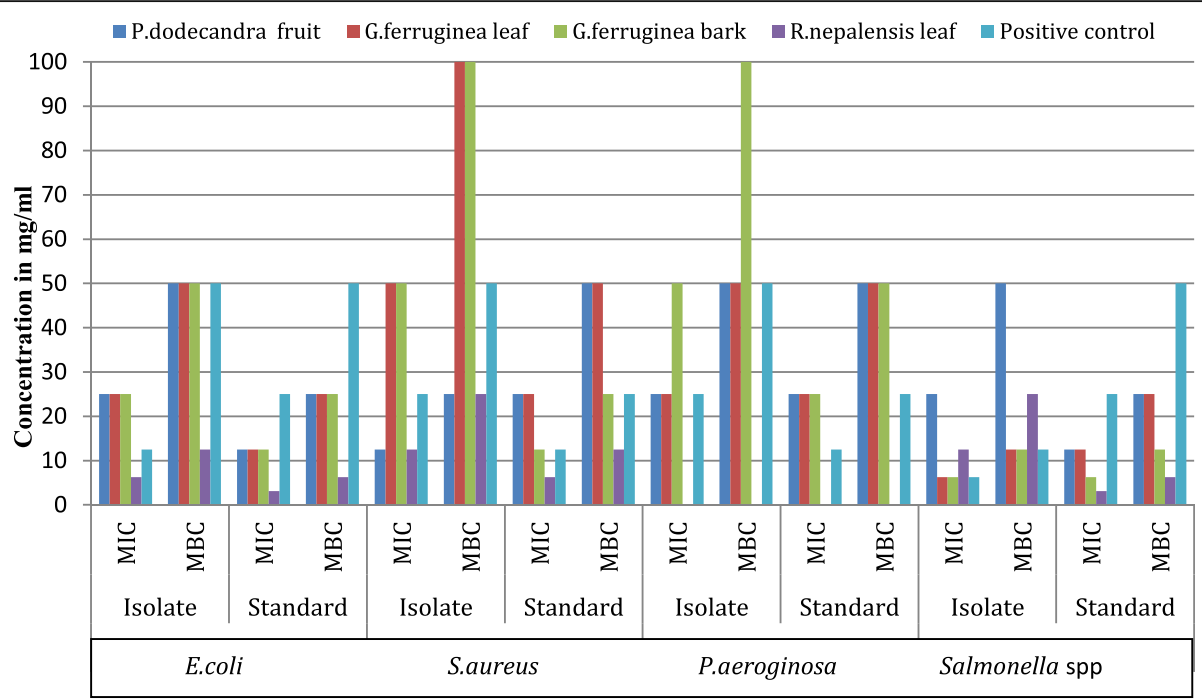

Bacteria strains

Fig. $1 \mathrm{MIC}$ and $\mathrm{MBC}$ of the test plants and the positive control against different bacterial species

and $\mathrm{MBC})$. The difference in antibacterial activity of the plants can be attributed to varying availability of the bioactive constituents. However, all of them contain effective bioactive constituents such as tannins, flavonoids and saponins in varying concentration. These constituents are effective against different bacterial species including resistant strains. Therefore, all the test plants are strong enough to replace commercial detergents and achieve good personal hygiene in rural areas where the accessibility or affordability of commercial detergents are limited or absent. These plants are abundantly available in rural areas to be a promising source of commercial antimicrobial agent production if further investigation is considered.

\section{Abbreviations}

DMSO: Dimethylsulfoxide; KIA: Klinger iron agar; LFCs: Lactose Fermenting Colonies; LIA: Lysine iron agar; MBC: Minimum Bactericidal Concentration; MHA: Mueller Hinton Agar; MIC: Minimum Inhibitory Concentration; NLFC: Non-lactose fermenting colonies; XLD: Xylose Lysine Desoxycholate

\section{Acknowledgements}

"Not applicable" in this section.

\section{Funding}

This study was supported by Jimma University College of public health and medical sciences research and post graduate office.

\section{Availability of data and materials}

Data sharing not applicable to this article as no datasets were generated or analyzed during the current study.

\section{Authors' contributions}

GTT (Gutema), designed the study, collected the data, did the experiment, analyzed the data, and wrote the first draft of the manuscript. GTT (Gudina) participated in the design of the study, supervised the whole process, reviewed and modified the draft of the manuscript. WBE (Wondwossen) participated in the study, supervision and review of manuscript. All authors read and approved the final manuscript.
Ethics approval and consent to participate

"Not applicable" in this section.

\section{Consent for publication}

"Not applicable" in this section.

\section{Competing interests}

The authors declare that they have no competing interests.

\section{Publisher's Note}

Springer Nature remains neutral with regard to jurisdictional claims in published maps and institutional affiliations.

Received: 19 April 2017 Accepted: 25 July 2017

Published online: 28 July 2017

\section{References}

1. Boyce JM, Pittet D. Guideline for hand hygiene in health-care settings: recommendations of the healthcare infection control practices advisory committee and the hicpac/shea/apic/idsa hand hygiene task force. Am J Infect Control. 2002;30(8):S1-S46.

2. Wolf R, et al. Soaps, shampoos, and detergents. Clin Dermatol. 2001; 19(4):393-7.

3. Simonne, A., Hand hygiene and hand sanitizers, in Department of Family, Youth and Community Sciences, Institute of Food and Agricultural Sciences (IFAS).2016, University of Florida.

4. Tambekar D, et al. Prevention of transmission of infectious disease: studies on hand hygiene in health-care among students. Cont J Biomed Sci. 2007;1: 6-10.

5. Tambekar DH, Shirsat SD. Hand washing: a cornerstone to prevent the transmission of Diarrhoeal infection. Asian J Med Sci. 2009;1(3):100-3.

6. Cossu A, et al. Assessment of sanitation efficacy against Escherichia Coli 0157: $\mathrm{H7}$ by rapid measurement of intracellular oxidative stress, membrane damage or glucose active uptake. Food Control. 2017;71:293-300.

7. Burton $\mathrm{M}$, et al. The effect of handwashing with water or soap on bacterial contamination of hands. Int J Environ Res Public Health. 2011;8(1):97-104.

8. Curtis V, Cairncross S. Effect of washing hands with soap on diarrhoea risk in the community: a systematic review. Lancet Infect Dis. 2003;3(5):275-81.

9. Biran $\mathrm{A}$, et al. The effect of a soap promotion and hygiene education campaign on handwashing behaviour in rural India: a cluster randomised trial. Tropical Med Int Health. 2009;14(10):1303-14.

10. Barnes, S., D. Concepcion, and G. Felizardo, Guide to the Elimination of Infections in Hemodialysis. Washington.-APIC.-2010.-78 p, 2010. 


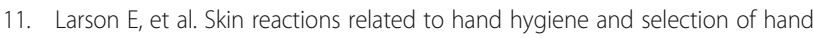
hygiene products. Am J Infect Control. 2006;34(10):627-35.

12. Revelas A. Acute gastroenteritis among children in the developing world: review. South Afr J Epidemiol Infect. 2012;27(4):156-62

13. Cowan MM. Plant products as antimicrobial agents. Clin Microbiol Rev. 1999:12(4):564-82.

14. Handali S, et al. Formulation and evaluation of an antibacterial cream from Oxalis Corniculata aqueous extract. Jundishapur J Microbiol. 2011:4(4):255-60

15. Wallace RJ. Antimicrobial properties of plant secondary metabolites. Proc Nutr Soc. 2004;63(04):621-9.

16. Ahmad I, Beg AZ. Antimicrobial and phytochemical studies on 45 Indian medicinal plants against multi-drug resistant human pathogens. J Ethnopharmacol. 2001;74(2):113-23.

17. Asafu Maradufu JKO, Sang BC, Khang'ati JE. Using Senecio lyratipartitus extract after anal ablution - Various documents on results from research grant. Baraton: University of Eastern Africa; 2013

18. Vyas P. Antimicrobial activity of ayurvedic hand sanitizers. Int J Pharm \& Bio Arch. 2011;2(2):1-5.

19. Wani NS, et al. Formulation and evaluation of herbal sanitizer. Int J PharmTech Res. 2013;5(1):40-3.

20. Geyid A, et al. Screening of some medicinal plants of Ethiopia for their anti-microbial properties and chemical profiles. J Ethnopharmacol. 2005; 97(3):421-7.

21. Suleman S, Alemu T. A survey on utilization of ethnomedicinal plants in Nekemte town, east Wellega (Oromia), Ethiopia. J Herbs, Spices Med Plants. 2012:18(1):34-57.

22. Tadeg $\mathrm{H}$, et al. Antimicrobial activities of some selected traditional Ethiopian medicinal plants used in the treatment of skin disorders. J Ethnopharmacol. 2005;100(1):168-75.

23. Aliyu A, et al. Activity of plant extracts used in northern Nigerian traditional medicine against methicillin-resistant Staphylococcus Aureus (MRSA). Nigerian J Pharm Sci. 2008:7(1):1-8

24. Mehta, P. and K. Bhatt, Traditional soap and detergent yielding plants of Uttaranchal. 2007.

25. Kumbi ET. Use and conservation of traditional medicinal plants by indigenous people in gimbi woreda, western wellega, ethiopia. Addis Ababa: Addis Ababa University; 2010.

26. Cannell RJ. How to approach the isolation of a natural product, in Natural Products Isolation: Springer; 1998. p. 1-51.

27. Tiwari $P$, et al. Phytochemical screening and extraction: a review. Internationale Pharmaceutica Sciencia. 2011;1(1):98-106.

28. Joshi B, et al. Phytochemical extraction and antimicrobial properties of different medicinal plants: Ocimum Sanctum (Tulsi), Eugenia Caryophyllata (clove), Achyranthes Bidentata (Datiwan) and Azadirachta Indica (Neem). Journal of Microbiology and Antimicrobials. 2011;3(1):1-7.

29. Longanga Otshudi A. A. Vercruysse, and A. Foriers, Contribution to the ethnobotanical, phytochemical and pharmacological studies of traditionally used medicinal plants in the treatment of dysentery and diarrhoea in Lomela area, Democratic Republic of Congo (DRC). J Ethnopharmacol. 2000; 71(3):411-23.

30. Yadav R, Agarwala M. Phytochemical analysis of some medicinal plants. Journal of phytology. 2011;3(12):1-5.

31. Joshi RK Chemical constituents and antibacterial property of the essential oil of the roots of Cyathocline purpurea. J Ethnopharmacol. 2013;145(2):621-5.

32. Al-Snafi AE. Chemical constituents and pharmacological effects of Citrullus Colocynthis-a review. IOSR Journal Of Pharmacy. 2016;6(3):57-67.

33. Ezema BE, Odoemelam El, Agbo MO. Phytochemical and antibiotic evaluation of the methanol extract of Loranthus Micranthus Linn parasitic on kola Accuminate. International Journal of PharmTech Research. 2016;9(2):176-81.

34. Boğa $\mathrm{M}$, et al. Phytochemical profile and some biological activities of three Centaurea species from Turkey. Trop J Pharm Res. 2016;15(9):1865-75.

35. Kalaiselvi V, Binu TV, Radha SR. Preliminary phytochemical analysis of the various leaf extracts of Mimusops Elengi L. South Indian J Biol Sci. 2016;2(1):24-9.

36. Coyle, M.B., Manual of antimicrobial susceptibility testing. 2005: American Society for Microbiology.

37. Jorgensen, J.H. and J.D. Turnidge, Susceptibility test methods: dilution and disk diffusion methods, in Manual of Clinical Microbiology, Eleventh Edition. 2015, American Society of Microbiology. p. 1253-1273.

38. CLSI, ed. Performance Standards for Antimicrobial Susceptibility Testing 26th Edition. ed. P.C.a.L.S.I. CLSI supplement M100S. Wayne. 2016, Clinical and Laboratory Standards Institute.
39. Atlas RM. Handbook of microbiological media, fourth edition, vol. 1-1953: CRC Press; 2010

40. Cheesbrough M. District laboratory practice in tropical countries: Cambridge university press; 2006

41. Kiehlbauch JA, et al. Use of the National Committee for clinical laboratory standards guidelines for disk diffusion susceptibility testing in New York state laboratories. J Clin Microbiol. 2000;38(9):3341-8.

42. CLSI, Methods for dilution antimicrobial susceptibility tests $f$ or bacteria that grow aerobically; approved St andard-ninth edition. CLSI document

M07-A9. Wayne, PA: 2012, Clinical and Laboratory Standards Institute.

43. Sule I, Agbabiaka T. Antibacterial effect of some plant extracts on selected Enterobacteriaceae. Ethnobotanical leaflets. 2008:2008(1):137.

44. Makut $\mathrm{M}$, et al. Phytochemical screening and antimicrobial activity of the ethanolic and methanolic extracts of the leaf and bark of Khaya Senegalensis. Afr J Biotechnol. 2008;7(9);1216-9.

45. Das K, Tiwari R, Shrivastava D. Techniques for evaluation of medicinal plant products as antimicrobial agents: current methods and future trends. J Medicinal Plants Res. 2010;4(2):104-11.

46. Jagessar R, Mohamed A, Gomes G. An evaluation of the antibacterial and antifungal activity of leaf extracts of Momordica Charantia against Candida Albicans, Staphylococcus Aureus and Escherichia Coli. Nature and Science. 2008;6(1):1-14.

47. Gupta A, Naraniwal M, Kothari V. Modern extraction methods for preparation of bioactive plant extracts. International Journal of Applied and Natural Sciences (IJANS). 2012;1(1):8-26.

48. Ichim E, Marutescu L, Popa M, Cristea S. Antimicrobial efficacy of some plant extracts on bacterial ring rot pathogen, Clavibacter michiganensis ssp. sepedonicus. The EuroBiotech Journal. 2017;1(1):93-6.

49. Mohan Ch M, Smitha PV. Phytochemical composition and antimicrobial activity of three plant preparations used in folk medicine and their synergistic properties. J Herbs, Spices \& Med Plants. 2011;17(4):339-50.

50. Njume C, Jide AA, Ndip RN. Aqueous and organic solvent-extracts of selected south African medicinal plants possess antimicrobial activity against drug-resistant strains of helicobacter pylori: inhibitory and bactericidal potential. Int J Mol Sci. 2011;12:5652-65.

51. Kumari I. Antibacterial activity of bud extract of Euphorbia Hirta L. against gram-positive bacteria Staphylococcus Aureus. Indian Journal of Applied Research. 2017:6(10);307-08.

52. Cushnie TT, Lamb AJ. Antimicrobial activity of flavonoids. Int J Antimicrob Agents. 2005;26(5):343-56

53. Maatalah MB, et al. Antimicrobial activity of the alkaloids and saponin extracts of anabasis articulata. J Biotechnol Pharm Res. 2012;3(3):54-7.

54. Aiello AE, et al. A comparison of the bacteria found on the hands of 'homemakers' and neonatal intensive care unit nurses. J Hosp Infect. 2003; 54(4):310-5

55. Chauhan, V., In vitro assessment of indigenous herbal and commercial antiseptic soaps for their antimicrobial activity, 2006, M. Sc. Dissertation in Biotechnology, Department of Biotechnology and Environmental Sciences, Thapar Institute of Engineering \& Technology, Deemed University, Patiala, India.

56. Biran A, et al. Effect of a behaviour-change intervention on handwashing with soap in India (SuperAmma): a cluster-randomised trial. Lancet Glob Health. 2014;2(3):e145-54.

57. Pittet D, Allegranzi B, Boyce J. The World Health Organization guidelines on hand hygiene in health care and their consensus recommendations. Infect Control Hosp Epidemiol. 2009:30(07):611-22. 